\title{
Species and genera of soil nematodes in forest ecosystems of the Vihorlat Protected Landscape Area, Slovakia
}

\author{
L. HÁNĚL ${ }^{1}$, A. ČEREVKOVÁ \\ ${ }^{1}$ Biology Centre AS CR, v. v. i., Institute of Soil Biology, Na Sádkách 7, CZ-370 05 České Budějovice, Czech \\ Republic, E-mail: hanel@upb.cas.cz; ${ }^{2}$ Parasitological Institute, Slovak Academy of Sciences, Hlinkova 3, \\ 04001 Košice, Slovak Republic, E-mail: cerev@saske.sk
}

\begin{abstract}
Summary
Fauna of soil nematodes was studied in three main forest types of the Vihorlat Mountains, Querceto-Fageto-Aceretum at Remetské Hámre (RH), Fagetum at Morské oko (MO), and Fageto-Aceretum at Sninský kameň (SK). Each forest type was represented by five sites. In total 198 species and 98 genera of soil nematodes were distinguished. Most species belonged to rare taxa with the frequency of occurrence lower than $50 \%$. The number of species and genera decreased from RH (167 species and 86 genera) through MO (115 and 68) to SK (87 and 51). Species and generic richness was significantly positively correlated with soil $\mathrm{pH}\left(\mathrm{H}_{2} \mathrm{O}\right)$, negatively with altitude, soil moisture and $\mathrm{C}_{\mathrm{ox}}$. Greater part of nematode species and genera belonged to microbivores and to the taxa with higher $\mathrm{cp}$ values of $3-5$. We can conclude that rich nematode fauna indicated undisturbed forest soil condition, nevertheless, the richness decreased with increasing altitude.
\end{abstract}

Keywords: Forest; soil nematodes; species richness; trophic diversity; maturity

\section{Introduction}

Nematodes are the most abundant multicellular animals (Bongers \& Ferris, 1999) and very likely the second most diverse phylum with about 27000 recently described species (estimated number up to 1000000 ) after arthropods (Huggot et al., 2001). Due to their diverse communities they significantly influence ecosystem processes, particularly in soil (Vinciguerra, 1979; Wasilewska, 1979; Bongers \& Bongers, 1998), and they are a useful indicator of soil condition in forest ecosystems (Yeates, 2007).

The fauna of soil nematodes in forest ecosystems of Slova- kia was relatively well studied (Šály, 1983; Lišková et al., 2008; Čerevková \& Renčo, 2009), but the eastern woodland of the Vihorlat mountains has not been paid attention till now. This territory is characterised by deciduous forests arranged in altitudinal gradient, moreover, these forests are still devoid of marked anthropogeneous disturbance. We selected three main forest types that characterise the Vihorlat woodland to study soil nematode communities as they vary with natural environment under low or negligible human intervention. This paper gives the first part of the study aimed at evaluation of species and generic richness in the Vihorlat woodland.

\section{Material and Methods}

Vihorlat Mountains is a volcanic (mostly andesite) mountain range in eastern Slovakia that belongs to the Inner Eastern Carpathians. The middle part of the mountains was established the Vihorlat Protected Landscape Area (4 500 ha) in 1973 . The area in mainly covered by natural deciduous forests with valuable beech ecosystems at the peak Vihorlat (1076 $\mathrm{m}$ a.s.1.) protected by UNESCO since 2007. Nematodes were studied in the vicinity of three localities described below. Values of soil parameters as gravimetric soil moisture, $\mathrm{pH}\left(\mathrm{H}_{2} \mathrm{O}\right)$, and $\mathrm{C}_{\mathrm{ox}}$ are given in arithmetical mean $\pm \mathrm{SE}$ (range of values), $\mathrm{n}=10$.

Remetské Hámre: RH, $48^{\circ} 50^{\prime} \mathrm{N}, 22^{\circ} 10^{\prime} \mathrm{E}, 403 \mathrm{~m}$ a.s.l., mean annual air temperature $5-7^{\circ} \mathrm{C}$, annual precipitation approximately $700-800 \mathrm{~mm}$. The vegetation is characterised by Querceto-Fageto-Aceretum forest type with shrub-rich mostly with Corylopsis, Ligustrum and Frangula alnus on cambisol. Soil moisture $=31.84 \pm 2.99$ $(15.21-46.74) \%, \mathrm{pH}\left(\mathrm{H}_{2} \mathrm{O}\right)=7.69 \pm 0.25(6.54-9.10)$, 


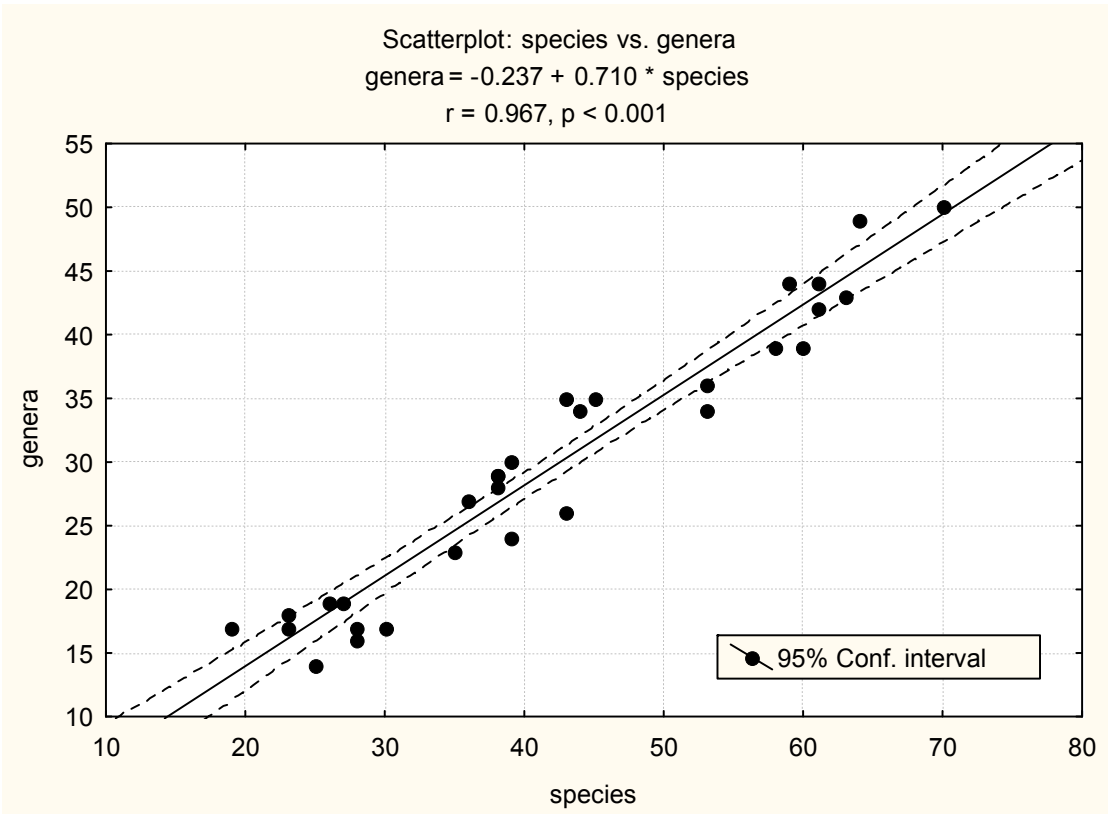

Fig. 1. Scatterplot with linear regression line fitted to the species versus genus numbers and $95 \%$ confidence intervals for that line.

$\mathrm{C}_{\mathrm{ox}}=8.81 \pm 0.70(5.95-12.50) \%$.

Morské oko: National Nature Reserve: $\mathrm{MO}, 48^{\circ} 54^{\prime} \mathrm{N}, 22^{\circ}$ $13^{\prime} \mathrm{E}, 618 \mathrm{~m}$ a.s.1., mean annual air temperature $4-5^{\circ} \mathrm{C}$, precipitation $800-1100 \mathrm{~mm}$. Vegetation is generally characterised by woody composition, where beech (Fagetum) has absolute superiority with poor or almost without herb cover undergrowth on clay-loamy cambisol. Soil moisture $=33.00 \pm 2.30(15.06-40.09) \%, \mathrm{pH}\left(\mathrm{H}_{2} \mathrm{O}\right)=6.94 \pm 0.10$ $(6.45-7.60), \mathrm{C}_{\mathrm{ox}}=11.09 \pm 0.96(4.63-15.27) \%$.

Sninský kameň: SK, $48^{\circ} 56^{\prime} \mathrm{N}, 22^{\circ} 12^{\prime} \mathrm{E}, 1005$ m a.s.l., mean annual air temperature $4-5^{\circ} \mathrm{C}$, precipitation 800 $1100 \mathrm{~mm}$. Forest vegetation is characterised by FagetoAceretum forest type on sandy-loamy cambisol. Herbaceous undergrowth is forming considerable layer characterised by the Cicerbita alpina. Due to harsh climate plants have limited growth. Soil moisture $=44.40 \pm 1.17$ (38.35$51.76) \%, \mathrm{pH}\left(\mathrm{H}_{2} \mathrm{O}\right)=6.18 \pm 0.13(5.66-7.06), \mathrm{C}_{\mathrm{ox}}=$ $18.21 \pm 0.84(13.50-22.13) \%$.

At each locality representing a forest type five plots each of 50 × $50 \mathrm{~m}$ were established. Soil samples were collected on

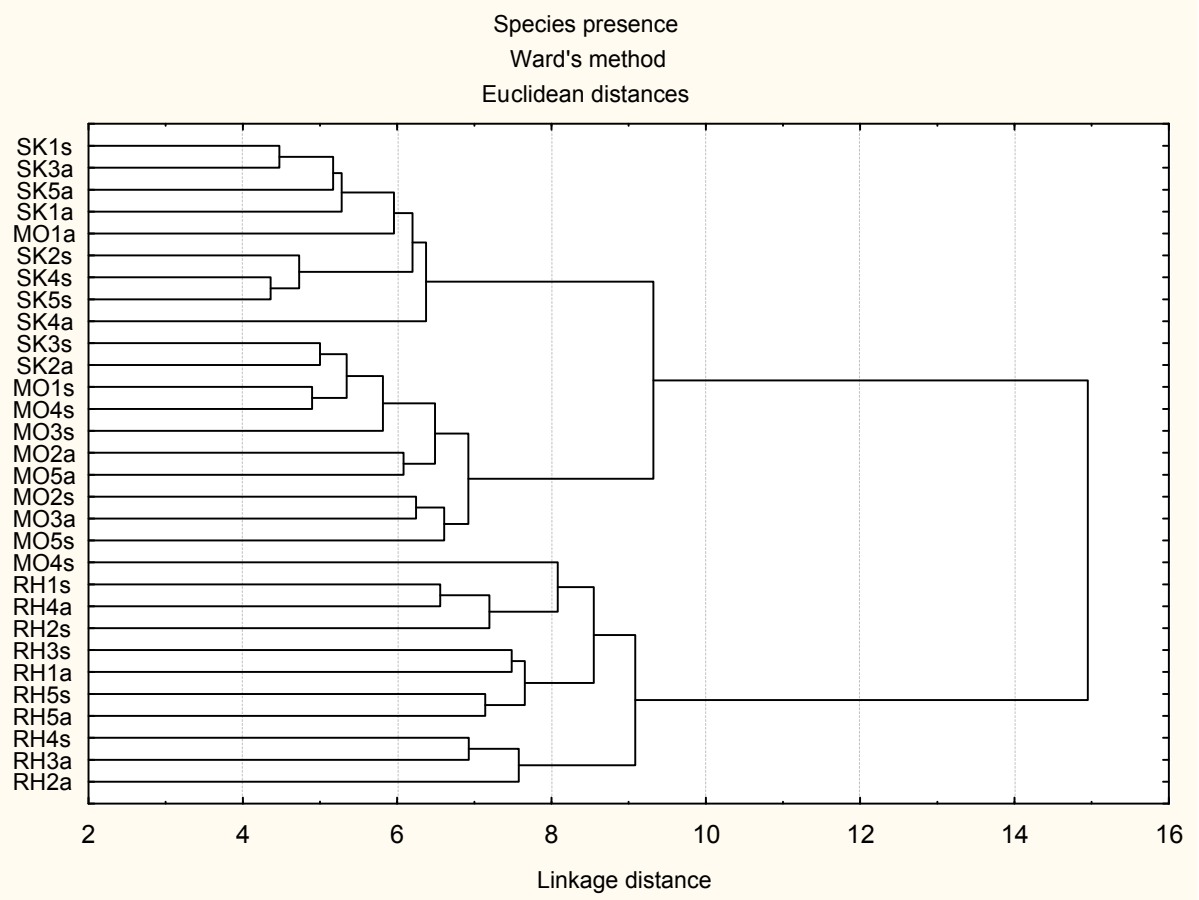

Fig. 2. Cluster analysis of nematode species in the Vihorlat woodland; localities RH = Remetské Hámre, $M O=$ Morské oko, SK = Sninský kameň; $1,2,3,4$, and $5=$ sites at individual localities; $\mathrm{s}=$ spring sampling date, $\mathrm{a}=$ autumn sampling date; the distance metric Euclidean distance on species presence and joining rule Ward's method. 
Table 1. Variation in nematode species and genus numbers in three forest types of the Vihorlat Mountains: Querceto-Fageto-Aceretum at Remetské Hámre (RH), Fagetum at Morské oko (MO), and Fageto-Aceretum Sninský kameň (SK). Different letters indicate significant differences as suggested by Fisher post-hoc tests $(\mathrm{p}<0.05)$ in one-way ANOVA.

\begin{tabular}{|c|c|c|c|c|c|c|c|c|c|}
\hline & & & & & & Species & & & \\
\hline & mean & $\mathrm{n}$ & $\mathrm{SD}$ & SE & minimum & maximum & $25 \%$ quantile & median & $75 \%$ quantile \\
\hline RH & $58.40^{\mathrm{a}}$ & 10 & 7.40 & 2.34 & 43.00 & 70.00 & 53.00 & 59.50 & 63.00 \\
\hline MO & $38.40^{\mathrm{b}}$ & 10 & 11.08 & 3.50 & 19.00 & 61.00 & 35.00 & 38.00 & 44.00 \\
\hline SK & $30.10^{\mathrm{c}}$ & 10 & 6.94 & 2.19 & 23.00 & 43.00 & 25.00 & 28.00 & 36.00 \\
\hline \multirow[t]{2}{*}{ All woodland } & 42.30 & 30 & 14.69 & 2.68 & 19.00 & 70.00 & 28.00 & 39.00 & 58.00 \\
\hline & mean & $\mathrm{n}$ & SD & SE & minimum & $\begin{array}{l}\text { Genera } \\
\text { maximum }\end{array}$ & $25 \%$ quantile & median & $75 \%$ quantile \\
\hline RH & $41.30^{\mathrm{a}}$ & 10 & 5.62 & 1.78 & 34.00 & 50.00 & 36.00 & 41.00 & 44.00 \\
\hline MO & $28.60^{\mathrm{b}}$ & 10 & 7.53 & 2.38 & 17.00 & 42.00 & 23.00 & 29.00 & 34.00 \\
\hline SK & $19.50^{\mathrm{c}}$ & 10 & 4.50 & 1.42 & 14.00 & 27.00 & 17.00 & 17.50 & 24.00 \\
\hline All woodland & 29.80 & 30 & 10.79 & 1.97 & 14.00 & 50.00 & 19.00 & 29.00 & 39.00 \\
\hline
\end{tabular}

2 April and 2 October 2008. At each site (plot) five soil subsamples covering an area of $100 \mathrm{~cm}^{2}$ down to the depth of $10 \mathrm{~cm}$ were taken using a hand spade. The soil was handmixed and nematodes were isolated from two $50 \mathrm{~g}$ portions of bulked soil using the Baermann funnel method. One nematode isolate was evaluated quantitatively to genus level. The second one was subjected to detailed study of species occurrence as many rare species in the first isolate were found only juvenile or were absent. Nematodes were fixed in FAA, mounted on permanent glycerol slides and determined to species level using light microscope Leica Leitz DMRB equipped with interference contrast. Statistical analyses were performed using the software package STATISTICA (StatSoft, 2001).
Nematodes were classified according to Andrássy (2005, 2007, 2009) and these books together with author's earlier works were used for the determination of nematodes. Tylenchida were mostly determined according to Brzeski (1998), some Dorylaimida according to Loof (1999) and further according to original descriptions and redescriptions in various papers. Species were allocated to trophic groups mainly using data on food preferences in genera as outlined by Yeates et al. (1993) and newer data, e.g. Okada $\&$ Kadota (2003). Cp values of species and genera were derived from cp values for families as given by Bongers \& Bongers (1998) using Bongers' (1988) allocations to families. Trophic diversity T (Freckman \& Ettema, 1993) and Sum Maturity Index $\sum$ MI (Yeates, 1994) were calcu-

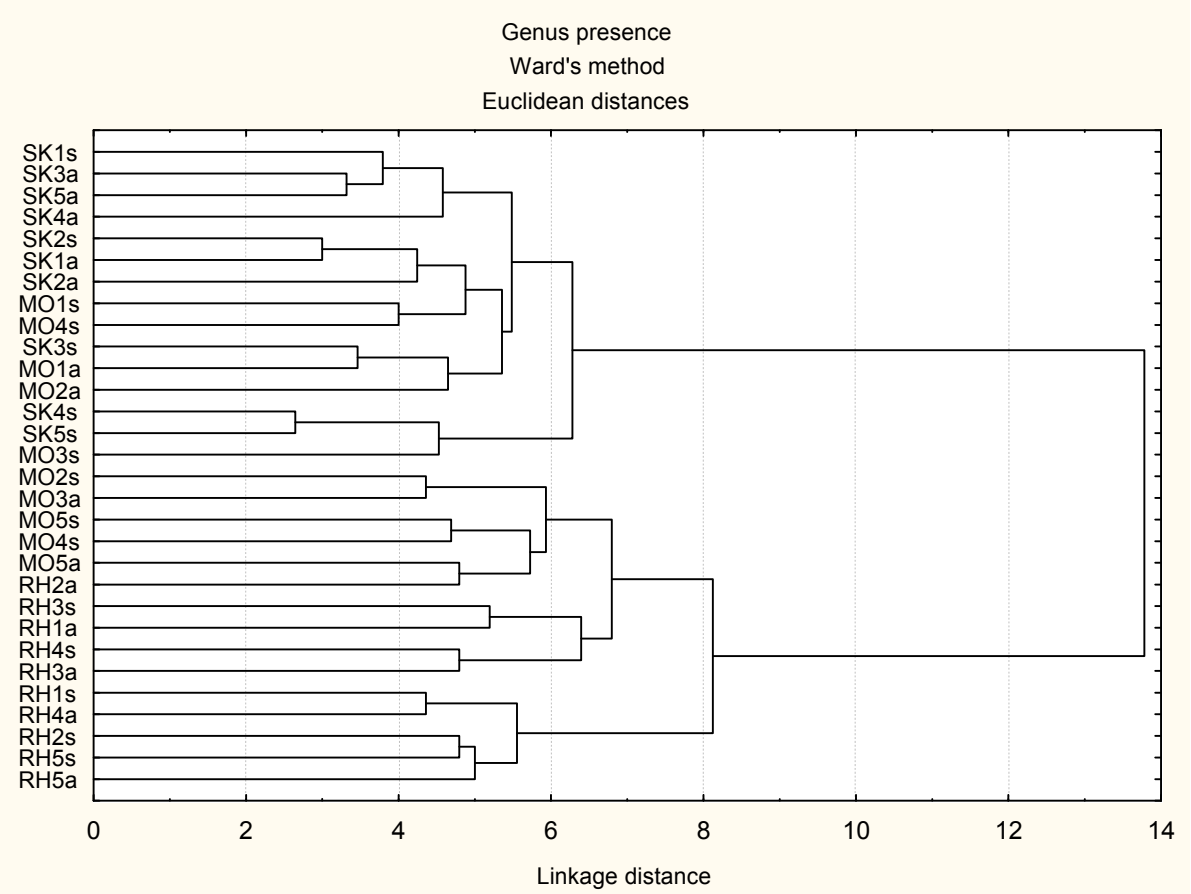

Fig. 3. Cluster analysis of nematode genera in the Vihorlat woodland; localities $\mathrm{RH}=$ Remetské Hámre, $\mathrm{MO}=\mathrm{Morské} \mathrm{oko,} \mathrm{SK}=\mathrm{Sninský}$ kameň;

$1,2,3,4$, and $5=$ sites at individual localities; $s=$ spring sampling date, a = autumn sampling date; the distance metric Euclidean distance on genus presence and joining rule Ward's method. 
lated either from the number of nematoda taxa in trophic groups or in cp groups, respectively; i.e. supposing that all species (genera) were present in a community and had the same abundance.
Kruskal-Wallis ANOVA and multiple comparisons of mean ranks for all groups supported significantly greater number of species $\left(\mathrm{H}_{(2, \mathrm{~N}=30)}=18.019, \mathrm{p}<0.001\right)$ and genera $\left(\mathrm{H}_{(2, \mathrm{~N}=30)}=21.048, \mathrm{p}<0.001\right)$ in $\mathrm{RH}$ than in SK, the effect of season was insignificant.

Table 2. Numbers of nematode species and genera in trophic groups and their percentage proportions to the total fauna with trophic diversity $\mathrm{T}$ index at individual localities and in all woodland.

\begin{tabular}{|c|c|c|c|c|c|c|c|c|}
\hline \multirow[b]{4}{*}{ Bacterivores } & \multicolumn{8}{|c|}{ Species } \\
\hline & \multicolumn{2}{|c|}{ RH } & \multicolumn{2}{|c|}{ MO } & \multicolumn{2}{|c|}{ SK } & \multicolumn{2}{|c|}{ All woodland } \\
\hline & No. & $\%$ & No. & $\%$ & No. & $\%$ & No. & $\%$ \\
\hline & 60 & 35.9 & 42 & 36.5 & 28 & 32.2 & 67 & 33.8 \\
\hline Fungivores & 27 & 16.2 & 14 & 12.2 & 16 & 18.4 & 32 & 16.2 \\
\hline Root-fungal feeders & 22 & 13.2 & 11 & 9.6 & 15 & 17.2 & 26 & 13.1 \\
\hline Plant parasites & 19 & 11.4 & 19 & 16.5 & 9 & 10.3 & 28 & 14.1 \\
\hline Omnivores & 22 & 13.2 & 20 & 17.4 & 12 & 13.8 & 27 & 13.6 \\
\hline Predators & 16 & 9.6 & 8 & 7.0 & 6 & 6.9 & 17 & 8.6 \\
\hline Insect parasites & 1 & 0.6 & 1 & 0.9 & 1 & 1.1 & 1 & 0.5 \\
\hline Sum & 167 & 100.0 & 115 & 100.0 & 87 & 100.0 & 198 & 100.0 \\
\hline \multirow[t]{4}{*}{$\mathrm{T}$} & 4.72 & & 4.55 & & 4.96 & & 4.91 & \\
\hline & \multicolumn{8}{|c|}{ Genera } \\
\hline & \multicolumn{2}{|c|}{ RH } & \multicolumn{2}{|c|}{$\mathrm{MO}$} & \multicolumn{2}{|c|}{ SK } & \multicolumn{2}{|c|}{ All woodland } \\
\hline & No. & $\%$ & No. & $\%$ & No. & $\%$ & No. & $\%$ \\
\hline Bacterivores & 32 & 37.2 & 26 & 38.2 & 19 & 37.3 & 37 & 37.8 \\
\hline Fungivores & 9 & 10.5 & 6 & 8.8 & 7 & 13.7 & 9 & 9.2 \\
\hline Root-fungal feeders & 8 & 9.3 & 74 & 5.9 & 6 & 11.8 & 9 & 9.2 \\
\hline Plant parasites & 13 & 15.1 & 11 & 16.2 & 7 & 13.7 & 16 & 16.3 \\
\hline Omnivores & 11 & 12.8 & 12 & 17.6 & 7 & 13.7 & 13 & 13.3 \\
\hline Predators & 12 & 14.0 & 8 & 11.8 & 4 & 7.8 & 13 & 13.3 \\
\hline Insect parasites & 1 & 1.2 & 1 & 1.5 & 1 & 2.0 & 1 & 1.0 \\
\hline Sum & 86 & 100.0 & 68 & 100.0 & 51 & 100.0 & 98 & 100.0 \\
\hline $\mathrm{T}$ & 4.61 & & 4.37 & & 4.64 & & 4.52 & \\
\hline
\end{tabular}

\section{Results}

In total 198 species and 98 genera of soil nematodes were distinguished (Appendix 1). Some nematodes could not be determined to species because of the absence of adults or if the adult specimens were present those could not be identified with the available species descriptions for certain. Of the 198 species only $26(13.13 \%)$ had the frequency of occurrence in the woodland $(F)$ greater than $49.99 \%$, of the 98 genera such were $19(19.39 \%)$. The numbers of species and genera were significantly positively correlated (Fig. 1., Pearson $\mathrm{r}=0.967, \mathrm{p}<0.001$; Spearman $\mathrm{R}=0.948$, $\mathrm{p}<0.001)$ and there also were significant positive correlations within individual forest types.

Most nematode species and genera were found in Querceto-Fageto-Aceretum at Remetské Hámre (RH). Two-way ANOVA (homogeneity of variances assumption was not violated) showed that species $\left(\mathrm{F}_{(2,24)}=26.959, \mathrm{p}<\right.$ $0.001)$ and genera $\left(F_{(2,24)}=31.289, \mathrm{p}<0.001\right)$ numbers in $\mathrm{RH}$ were significantly greater than in MO and SK. MO had significantly more species and genera than SK (Table 1). The effect of season (spring and autumn sampling) upon the numbers of species and genera was insignificant.
The cluster analysis on species occurrence (Fig. 2) produced two main clusters, the upper one having two sub-clusters consisting of SK and MO samples (except for MO1a, SK3s and SK2a). The lower cluster consisted of RH samples plus MO4s. The cluster analysis on genus occurrence (Fig. 3) produced two main clusters, the upper one consisting of SK and MO samples and the lower one consisting of MO and RH samples.

The number of species over the Vihorlat woodland sites and sampling dates $(\mathrm{n}=30)$ was significantly positively correlated with $\mathrm{pH}\left(\mathrm{H}_{2} \mathrm{O}\right)(\mathrm{r}=0.529, \mathrm{p}=0.003)$, negatively correlated with soil moisture $(\mathrm{r}=-0.558, \mathrm{p}=0.001), \mathrm{C}_{\mathrm{ox}}(\mathrm{r}$ $=-0.612, \mathrm{p}<0.001)$, and with altitude $(\mathrm{r}=-0.758, \mathrm{p}<$ $0.001)$. The number of genera was significantly positively correlated with $\mathrm{pH}\left(\mathrm{H}_{2} \mathrm{O}\right)(\mathrm{r}=0.580, \mathrm{p}=0.001)$, negatively correlated with soil moisture $(\mathrm{r}=-0.625, \mathrm{p}<0.001), \mathrm{C}_{\mathrm{ox}}(\mathrm{r}$ $=-0.697, \mathrm{p}<0.001)$, and with altitude $(\mathrm{r}=-0.815, \mathrm{p}<$ $0.001)$, Fig. 4. Spearman R gave very similar values. Soil $\mathrm{pH}\left(\mathrm{H}_{2} \mathrm{O}\right)$ was negatively correlated with increasing altitude $(\mathrm{r}=-0.759, \mathrm{p}<0.001, \mathrm{n}=30)$ whereas soil moisture and $\mathrm{C}_{\mathrm{ox}}$ were positively correlated with the altitude $(\mathrm{r}=0.614, \mathrm{r}$ $=0.840, \mathrm{p}<0.001, \mathrm{n}=30$, respectively). The altitudinal gradient studied manifested in accumulation of soil organic 
Scatterplot: $\mathrm{pH}\left(\mathrm{H}_{2} \mathrm{O}\right)$ vs. species

species $=-23.460+9.480 * \mathrm{pH}$ $r=0.529, p=0.003$

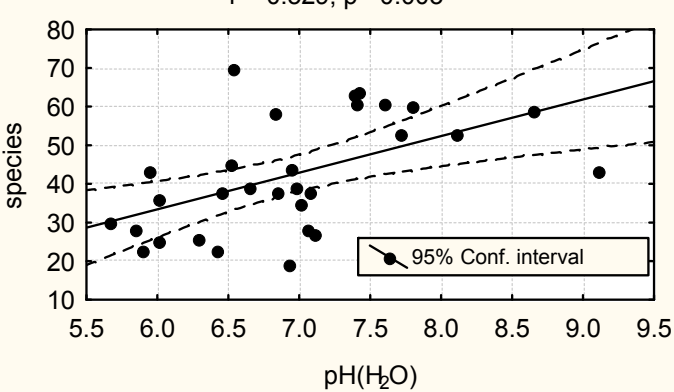

Scatterplot: \%water vs. species species $=75.369-0.908 * \%$ water $r=-0.558, p=0.001$

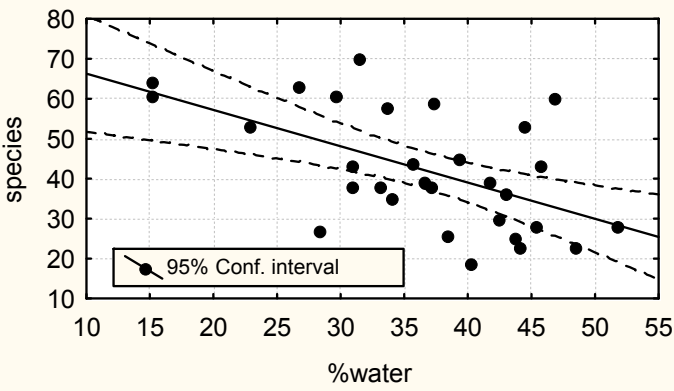

Scatterplot: $C_{o x}$ vs. species species $=66.040-1.869{ }^{*} \mathrm{C}_{\mathrm{ox}}$

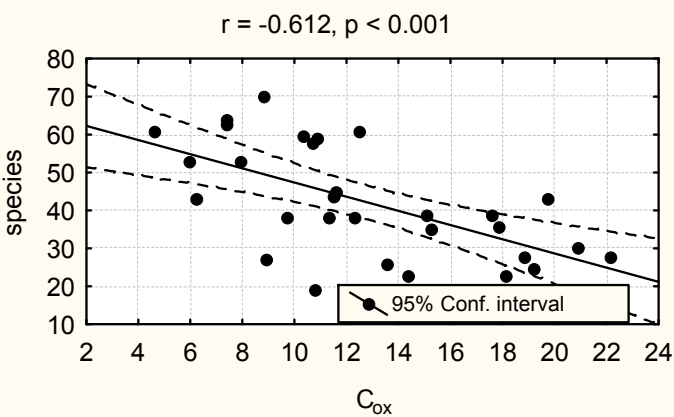

Scatterplot: altitude vs. species species $=71.989-0.044{ }^{*}$ altitude $r=-0.758, p<0.001$

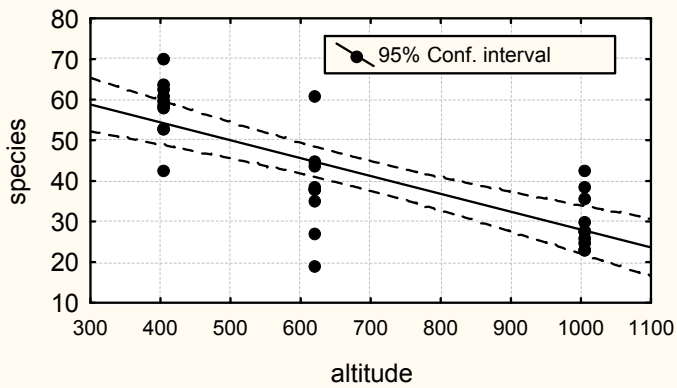

Scatterplot: $\mathrm{pH}\left(\mathrm{H}_{2} \mathrm{O}\right)$ vs. genera genera $=-23.120+7.629 * \mathrm{pH}$ $r=0.580, p=0.001$

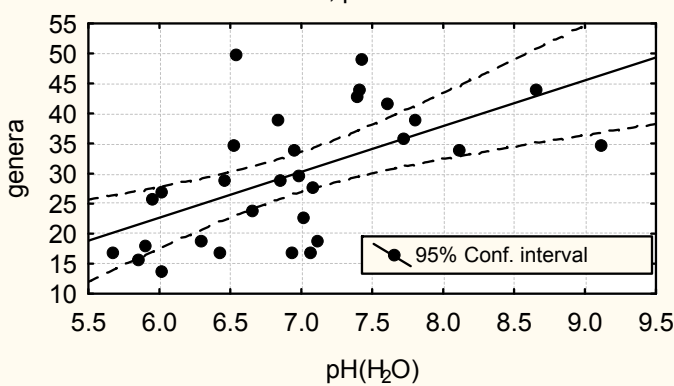

Scatterplot: \%water vs. genera genera $=56.968-0.746$ * \%water $r=-0.625, p<0.001$

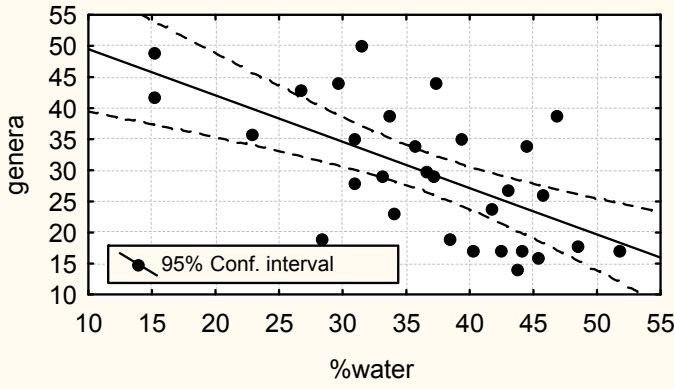

Scatterplot: $\mathrm{C}_{\mathrm{ox}}$ vs. genera genera $=49.640-1.562{ }^{*} \mathrm{C}_{\mathrm{ox}}$ $r=-0.697, p<0.001$

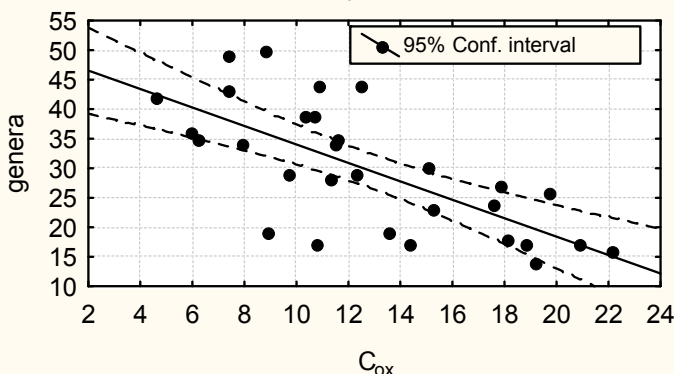

Scatterplot: altitude vs. genera genera $=53.233-0.035$ * altitude $r=-0.815, p<0.001$

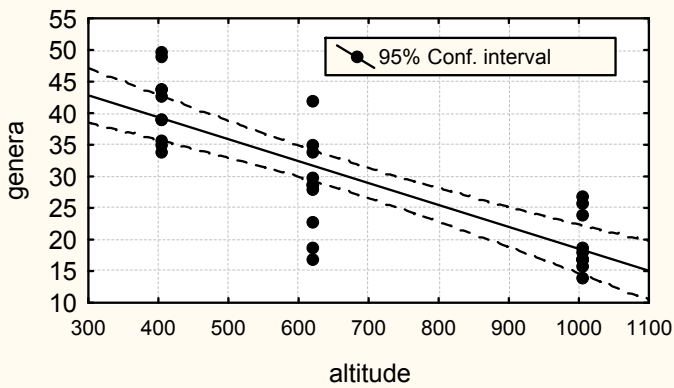

Fig. 4. Scatterplots with linear regression lines fitted to the species and genus numbers versus environmental variables $\left(\mathrm{soil} \mathrm{pH}\left(\mathrm{H}_{2} \mathrm{O}\right)\right.$, gravimetric soil moisture as $\%$ water in wet soil, $\mathrm{C}_{\mathrm{ox}} \%$ in dry soil, and altitude in $\mathrm{m}$ a.s.1.) and $95 \%$ confidence intervals for that line. 
Table 3. Numbers of nematode species and genera in cp groups and their percentage proportions to the total fauna with Sum Maturity Index $\sum$ MI at individual localities and in all woodland.

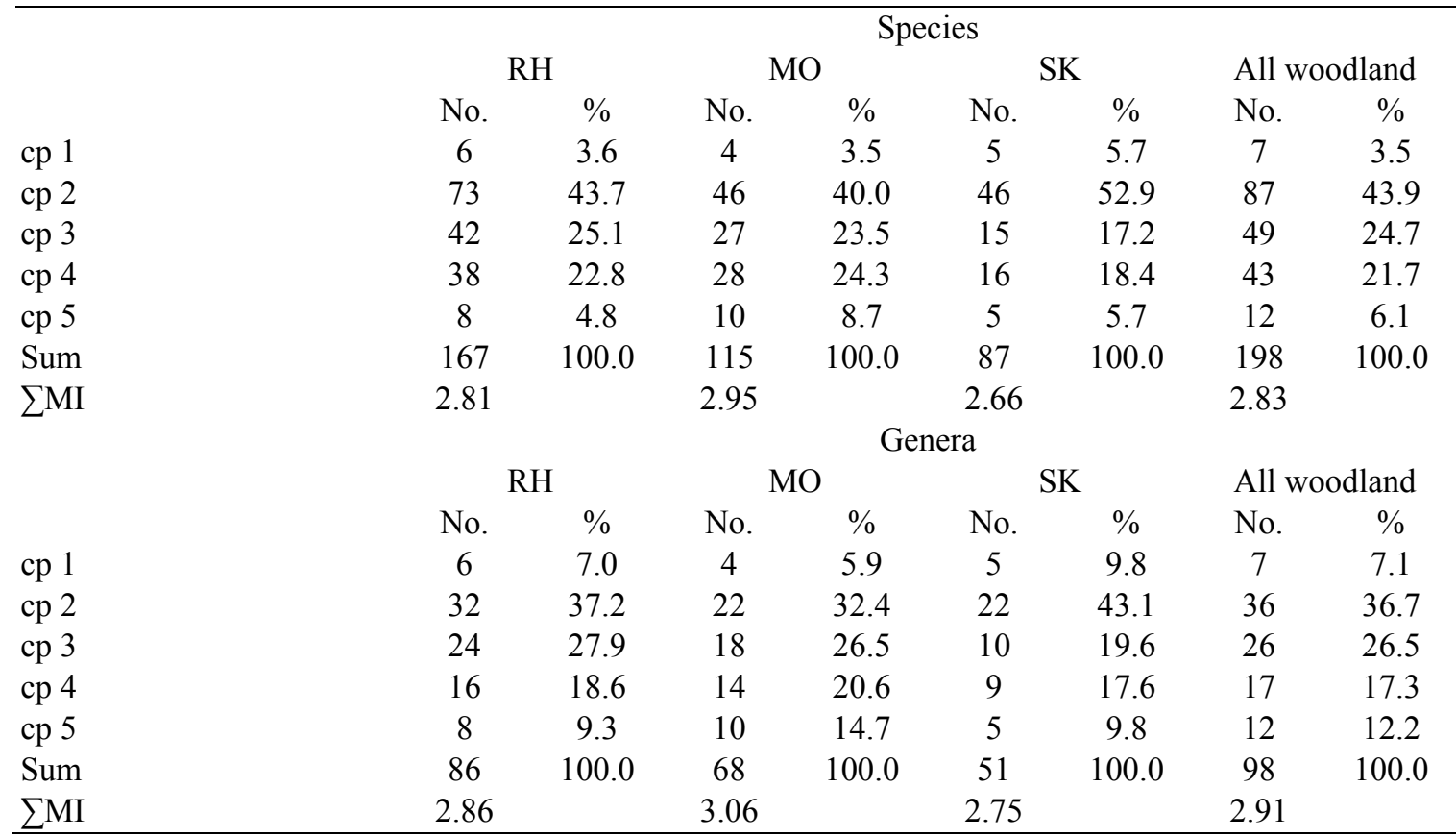

matter and lowered $\mathrm{pH}\left(\mathrm{H}_{2} \mathrm{O}\right)$ under wetter and cooler climate and combination of these factors negatively affected nematode richness.

Microbivorous species and genera prevailed in nematode fauna of the Vihorlat woodland. The number of species and genera in all trophic groups was always lower at SK than at RH. Consistent decrease from RH through MO to $\mathrm{SK}$ was found in the number of bacterivorous species and genera, predaceous species and genera, omnivorous species, and plant parasitic genera. Such trend was not observed in the values of the T index (Table 2).

More nematode species and genera belonged to the groups with higher cp scaling (together for 3, 4 and 5) than to the groups with lower cp scaling (together for 1 and 2). The number of species and genera in all $\mathrm{cp}$ groups was always lower at SK than at RH. Consistent decrease from RH through $\mathrm{MO}$ to $\mathrm{SK}$ in the number of species and genera was observed for cp groups 3 and 4 . The values of $\sum \mathrm{MI}$ index for both species and genera were lower at SK than at $\mathrm{RH}$, greatest values were at MO (Table 3 ).

\section{Discussion}

The nematode fauna in the Vihorlat Mountains had a great species and generic richness as in similar woodland landscapes of Central Europe. For example, Šály (1985) found 182 species of soil nematodes in the Slovak Paradise, Andrássy (1996) 122 species in the Bükk Mountains, and Háněl (1996a) 138 species in the Křivoklátsko woodland. Very high species and generic richness were found in Querceto-Fageto-Aceretum woodland at RH when compared with other European deciduous ecosystems (e.g.
Alphei, 1998; Büttner, 1989; Popovici, 1989) very likely due to favourable climate and rich plant community.

Nematode species and genera were significantly positively correlated as in our study on meadow ecosystems (Háněl \& Čerevková, 2006) and in tree plantations on colliery spoils (Háněl, 2009). Therefore, genus richness is a sufficient estimator of overall nematode richness although species can better distinguish different types of ecosystems (Figs. 1 and 2). Majority of nematode species belonged to rare or very rare animals (Appendix 1), which suggested a great variety of microhabitats and low degree of disturbance to the Vihorlat woodland.

We found decline in species and generic richness with increasing altitude. Similar trend was observed in spruce forests of the Beskydy mountains (Háněl, 1996b). Also Ruess et al. (2001) found greater nematode richness at the low altitude heath than at the high altitude fellfield in arctic soils. On the other hand nematode richness in Romanian grasslands studied by Popovici and Ciobanu (2000) did not appear to be affected by altitude, with an exception for Vladeasa Mts. where nematode richness tended to decline with increasing altitude. Reverse trends can also occur as a low nematode richness in spruce plantations in lowlands (Háněl, 1992) compared to a higher richness in semi-natural spruce forests in mountains (Háněl, 2004).

Nematode taxomic richness was found to exhibit consistent correlations with mass and activity parameters of both nematofauna and microflora in the European mineral grassland soils (Ekschmitt et al., 2001) and the authors considered high nematode richness a good indicator of the decomposition function. More diverse nematode assemblages contribute to more resilient ecosystem services 
(Yeates, 2007). Thus, our data suggested faster nutrient cycling in lower altitudes of the Vihorlat woodland than in higher. Recovery from disturbance to forest ecosystem at SK could therefore be slower than at RH.

In contrast to the decrease in species and genus richness from RH through MO to SK trophic diversity (T) and maturity $\left(\sum \mathrm{MI}\right)$ of nematode faunas showed little variation (Tables 2 and 3). Ettema (1998) suggested that considerable functional redundancy probably exists at least in bacterivore nematodes however soil nematode diversity is important for long-term stability of soil functioning. Climatically harsh high-altitude sites can be especially sensitive to the impact of perturbations on nematode faunas due to lower initial biodiversity (i.e. redundancy) at such sites (Ruess et al., 2001). The results from the Vihorlat could indicate that species redundancy in nematode fauna occurred at RH compared to that at SK whereas potential functioning of soil nematode communities sustained unchanged and maintained at different levels of species richness.

Nevertheless, recently available cp scaling of nematode taxa should be taken with caution. For example, Plectus reproduces slowly than Acrobeloides and may be scaled higher on the cp scale relative to Acrobeloides (PostmaBlaauw et al., 2005). Fiscus \& Neher (2002) found different responses of some nematode genera to soil disturbances than could be expected with respect to their $\mathrm{cp}$ values. Allocation of nematode species to feeding groups is often uncertain (Yeates, 2003). Moreover, harsher climate at SK compared to RH could constrain nematode community (and other soil biota) from full functioning and change proportion between bacteria-based and fungal-based decomposition channels. Evaluation of abundance data on nematode genera, a topic of further study, can throw more light on actual functioning of nematode communities in the Vihorlat woodland.

\section{Acknowledgements}

The study was carried out as a part of the IRP ISB BC AS CR AV0Z60660521 and VEGA project No. 2/7191/27 SAS. Study stays were realised within frame of the priority theme of cooperation between AS CR and SAS for the period of 2008 - 2010 "Nematode communities of the Vihorlat Protected Landscape Area in Slovakia".

Appendix 1. Check-list of nematode species with the number of positives samples at the localities SK, MO and RH, total frequency of occurrence $\mathrm{F}[\%]$ in all Vihorlat woodland. tg = allocation of species to trophic groups B (bacterivores), F (fungivores), RFF (root-fungal feeders), PP (plant parasites), $\mathrm{P}$ (predators), $\mathrm{O}$ (omnivores), and IP (insect parasites). $\mathrm{cp}=$ allocation of species to cp groups $1-5$. $\mathrm{N}=\mathrm{species}$ new to Slovakia

\begin{tabular}{|c|c|c|c|c|c|c|c|}
\hline No. & Species in orders & $\operatorname{tg}$ & $\mathrm{cp}$ & SK & MO & RH & $\mathrm{F}[\%]$ \\
\hline & Monhysterida De Coninck \& Schuurmans Stekhoven, 1933 & & & & & & \\
\hline 1 & Eumonhystera dispar (Bastian, 1865) & $\mathrm{B}$ & 2 & 0 & 0 & 1 & 3.33 \\
\hline 2 & Eumonhystera longicaudatula (Gerlach et Riemann, 1973) & $\mathrm{B}$ & 2 & 0 & 4 & 5 & 30.00 \\
\hline 3 & Eumonhystera vulgaris (de Man, 1880) & $\mathrm{B}$ & 2 & 0 & 1 & 7 & 26.67 \\
\hline 4 & Eumonhystera sp. & $\mathrm{B}$ & 2 & 0 & 1 & 2 & 10.00 \\
\hline \multirow[t]{2}{*}{5} & Geomonhystera villosa (Bütschli, 1873) & $\mathrm{B}$ & 2 & 0 & 1 & 5 & 20.00 \\
\hline & Araeolaimida De Coninck \& Schuurmans Stekhoven, 1933 & & & & & & \\
\hline $6 \mathrm{~N}$ & Cylindrolaimus communis de Man, 1880 & $\mathrm{~B}$ & 3 & 0 & 2 & 4 & 20.00 \\
\hline 7 & Domorganus sp. & $\mathrm{B}$ & 3 & 0 & 0 & 2 & 6.67 \\
\hline $8 \mathrm{~N}$ & Bastiania uncinata Andrásssy, 1991 & $\mathrm{~B}$ & 3 & 0 & 4 & 9 & 43.33 \\
\hline $9 \mathrm{~N}$ & Bastiania vesca Eroshenko, 1977 & $\mathrm{~B}$ & 3 & 0 & 0 & 2 & 6.67 \\
\hline $10 \mathrm{~N}$ & Odontolaimus chlorurus de Man, 1880 & $\mathrm{~B}$ & 3 & 0 & 6 & 2 & 26.67 \\
\hline 11 & Rhabdolaimus terrestris de Man, 1880 & $\mathrm{~B}$ & 3 & 0 & 1 & 0 & 3.33 \\
\hline 12 & Anaplectus granulosus (Bastian, 1865) & $\mathrm{B}$ & 2 & 2 & 5 & 10 & 56.67 \\
\hline 13 & Plectus acuminatus Bastian, 1865 & $\mathrm{~B}$ & 2 & 9 & 8 & 9 & 86.67 \\
\hline $14 \mathrm{~N}$ & Plectus amorphotelus Ebsary, 1985 & $\mathrm{~B}$ & 2 & 6 & 5 & 0 & 36.67 \\
\hline 15 & Plectus communis Bütschli, 1873 & $\mathrm{~B}$ & 2 & 2 & 2 & 2 & 20.00 \\
\hline $16 \mathrm{~N}$ & Plectus exinocaudatus Truskova, 1976 & $\mathrm{~B}$ & 2 & 0 & 1 & 1 & 6.67 \\
\hline 17 & Plectus geophilus de Man, 1880 & $\mathrm{~B}$ & 2 & 3 & 1 & 6 & 33.33 \\
\hline 18 & Plectus longicaudatus Bütschli, 1873 & $\mathrm{~B}$ & 2 & 8 & 6 & 9 & 76.67 \\
\hline 19 & Plectus parietinus Bastian, 1865 & $\mathrm{~B}$ & 2 & 7 & 7 & 5 & 63.33 \\
\hline 20 & Plectus parvus Bastain, 1865 & $\mathrm{~B}$ & 2 & 0 & 2 & 2 & 13.33 \\
\hline 21 & Plectus rhizophilus de Man, 1880 & $\mathrm{~B}$ & 2 & 0 & 0 & 4 & 13.33 \\
\hline 22 & Plectus sp. & $\mathrm{B}$ & 2 & 0 & 0 & 1 & 3.33 \\
\hline $23 \mathrm{~N}$ & Chiloplectus cancellatus (Zullini, 1978) & $\mathrm{B}$ & 2 & 3 & 2 & 0 & 16.67 \\
\hline 24 & Ceratoplectus armatus (Bütschli, 1873) & $\mathrm{B}$ & 2 & 0 & 1 & 7 & 26.67 \\
\hline 25 & Tylocephalus auriculatus (Bütschli, 1873) & B & 2 & 2 & 4 & 5 & 36.67 \\
\hline
\end{tabular}


$26 \mathrm{~N}$ Tylocephalus cf. laticollis Zell, 1985 juv.

$27 \mathrm{~N} \quad$ Ereptonema arcticum Loof, 1971

28 Wilsonema otophorum (de Man, 1880)

29

30

31

$32 \mathrm{~N}$

$33 \mathrm{~N}$

$34 \mathrm{~N}$

$35 \mathrm{~N}$

$36 \mathrm{~N}$

37

38

39

40

41

$42 \mathrm{~N}$

43

44

45

46

47

48

$49 \mathrm{~N}$

$50 \mathrm{~N}$

51

52

53

54

55

56

57

58

59

$60 \mathrm{~N}$

$61 \mathrm{~N}$

$62 \mathrm{~N}$

$63 \mathrm{~N}$

$64 \mathrm{~N}$

$65 \mathrm{~N}$

$66 \mathrm{~N}$

67

$68 \mathrm{~N}$

69

70

71

$72 \mathrm{~N}$

Chromadorida Chitwood, 1933

Achromadora tenax (de Man, 1876)

Rhabditida Chitwood, 1933

Teratocephalus dadayi Andrássy, 1968

Teratocephalus lirellus Anderson, 1969

Teratocephalus tenuis Andrássy, 1956

Teratocephalus terrestris Bütschli, 1873

Teratocephalus sp.

Cephalobus persegnis Bastian, 1865

Bunobus loofi (Andrássy, 1968)

Wasilewska, 1963)

Acrobeloides nanus (de Man, 1880)

Chiloplacus sp.

Acrobelophis minimus (Thorne, 1925)

Cervidellus vexilliger (de Man, 1880) 1973

Steinernema dauer larvae

Rhabditis terricola Dujardin, 1845

Protorhabditis filiformis (Bütschli, 1873)

Bursilla monhystera (Bütschli, 1873)

Diplogasteritus sp. juv.

Aphelenchida Siddiqi, 1980

Aphelenchus avenae Bastian, 1865

Aphelenchoides curiolis Gritsenko, 1971

Aphelenchoides rarus Eroshenko, 1968

Aphelenchoides sp.

Seinura variobulbosa Haque, 1966

Tylenchida Thorne, 1949

Aglenchus agricola (de Man, 1884)

Coslenchus sp. $1^{3)}$

Coslenchus sp. $2^{3)}$

Filenchus cf. aquilonius (Wu, 1969) ${ }^{4)}$
Wilsonema schuurmansstekhoveni (De Coninck, 1931)

Metateratocephalus crassidens (de Man, 1880)

Metateratocephalus gracilicaudatus Andrássy, 1985

Prodesmodora cf. arctica (Mulvey, 1969)

Teratocephalus paratenuis Eroshenko, 1973

Heterocephalobus elongatus (de Man, 1880)

Eucephalobus mucronatus (Kozlowska et Roguska-

Eucephalobus oxyuroides (de Man, 1876)

Deficephalobus cf. humophilus Zell, 1987

Drilocephalobus coomansi Ali, Suryawanshi et Christy,

Panagrolaimus rigidus (Schneider, 1866)

Pristionchus cf. lheritieri (Maupas, 1919)

Paraphelenchus pseudoparietinus Micoletzky, 1922

Aphelenchoides conimucronatus Bessarabova, 1966

Aphelenchoides cf. eradicitus Eroshenko, $1968{ }^{1)}$

Aphelenchoides lagenoferrus Baranovskaya, $1963^{2)}$

Aphelenchoides macronucleatus Baranovskaya, 1963

Aphelenchoides parasubtenius Shavrov, 1967

\begin{tabular}{|c|c|c|c|c|c|}
\hline 3 & & 0 & 0 & 1 & 3.33 \\
\hline B & & & 1 & & 33 \\
\hline B & & & 7 & & 46.67 \\
\hline B & & & $I_{0}$ & & 26.67 \\
\hline B & & & 2 & & 36.67 \\
\hline B & & & & 4 & 3.33 \\
\hline B & & 0 & 0 & 1 & 3.33 \\
\hline B & & 0 & 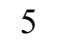 & 9 & 46.67 \\
\hline B & & 0 & 0 & 2 & 6.67 \\
\hline B & & & 7 & & 76.67 \\
\hline B & & & 1 & & 16.67 \\
\hline B & & & & & 3.33 \\
\hline B & & & 0 & 3 & 10.00 \\
\hline B & & & 0 & 3 & 0.00 \\
\hline B & & & 0 & 4 & 3.33 \\
\hline B & & & 3 & 6 & 46.67 \\
\hline B & & & 1 & 1 & 13.33 \\
\hline $\mathrm{D}$ & & 0 & 0 & 1 & 3.33 \\
\hline B & & 0 & 1 & 6 & 23.33 \\
\hline B & & 10 & 10 & 10 & 100.00 \\
\hline B & & 1 & 0 & 4 & 16.67 \\
\hline B & & & 0 & 3 & 00 \\
\hline B & & & 7 & 7 & 63.33 \\
\hline B & & & 0 & 0 & 6.67 \\
\hline B & & 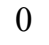 & 0 & 1 & 3.33 \\
\hline B & & 4 & 0 & 5 & 30.00 \\
\hline IP & & & 5 & 5 & 46.67 \\
\hline B & & 9 & 10 & 10 & 96.67 \\
\hline $\mathrm{B}$ & & & 0 & 1 & 33 \\
\hline B & & & 3 & 7 & 36.67 \\
\hline B & & & 0 & 0 & 3.33 \\
\hline B & 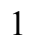 & 0 & 1 & 2 & 10.00 \\
\hline $\mathrm{F}$ & & & 0 & 3 & 13.33 \\
\hline $\mathrm{F}$ & & & 0 & 1 & 3.33 \\
\hline $\mathrm{F}$ & & & 0 & 1 & 6.67 \\
\hline $\mathrm{F}$ & & & 6 & 7 & 56.67 \\
\hline $\mathrm{F}$ & & & 0 & 0 & 33 \\
\hline $\mathrm{F}$ & 2 & 8 & 5 & 7 & 6.67 \\
\hline $\mathrm{F}$ & & $\varepsilon$ & 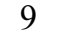 & 8 & 33 \\
\hline $\mathrm{F}$ & 2 & 7 & 6 & 8 & 70.00 \\
\hline $\mathrm{F}$ & & & 0 & 1 & 3.33 \\
\hline F & & 0 & 2 & 2 & 13.33 \\
\hline $\mathrm{P}$ & 2 & 0 & 0 & 1 & 3.33 \\
\hline & & & 0 & U & 33 \\
\hline & 2 & & 1 & 1 & 10.00 \\
\hline 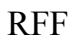 & 2 & 0 & 1 & 0 & 3.33 \\
\hline Г & & 1 & 0 & 3 & 13.33 \\
\hline
\end{tabular}




\begin{tabular}{|c|c|c|c|c|c|c|c|}
\hline $73 \mathrm{~N}$ & Filenchus baloghi (Andrássy, 1958) & RFF & 2 & 0 & 0 & 1 & 3.33 \\
\hline $74 \mathrm{~N}$ & Filenchus discrepans (Andrássy, 1954) & RFF & 2 & 5 & 5 & 6 & 53.33 \\
\hline $75 \mathrm{~N}$ & Filenchus facultativus (Szczygiel, 1970) & RFF & 2 & 8 & 4 & 6 & 60.00 \\
\hline $76 \mathrm{~N}$ & Filenchus longicaudatulus Zell, 1988 & RFF & 2 & 8 & 4 & 8 & 66.67 \\
\hline $77 \mathrm{~N}$ & Filenchus misellus Andrássy, 1958 s.1. ${ }^{5)}$ & RFF & 2 & 10 & 10 & 10 & 100.00 \\
\hline 78 & Filenchus spicatus (Brzeski, 1986) $\left.{ }^{6}\right)$ & RFF & 2 & 7 & 6 & 10 & 76.67 \\
\hline $79 \mathrm{~N}$ & Filenchus vulgaris (Brzeski, 1963) & RFF & 2 & 2 & 1 & 1 & 13.33 \\
\hline 80 & Filenchus sp. 1 & RFF & 2 & 1 & 0 & 1 & 6.67 \\
\hline 81 & Filenchus sp. 2 & RFF & 2 & 0 & 0 & 2 & 6.67 \\
\hline 82 & Filenchus sp. 3 & RFF & 2 & 1 & 1 & 0 & 6.67 \\
\hline 83 & Basiria gracilis (Thorne, 1949) & RFF & 2 & 0 & 0 & 1 & 3.33 \\
\hline $84 \mathrm{~N}$ & Basiria tumida (Colbran, 1960) & RFF & 2 & 0 & 0 & 2 & 6.67 \\
\hline 85 & Basiria sp. & RFF & 2 & 0 & 0 & 1 & 3.33 \\
\hline 86 & Boleodorus thylactus Thorne, 1941 & RFF & 2 & 1 & 3 & 4 & 26.67 \\
\hline 87 & Neopsilenchus magnidens (Thorne, 1949) & RFF & 2 & 0 & 0 & 1 & 3.33 \\
\hline $88 \mathrm{~N}$ & Malenchus acarayensis Andrássy, 1968 & RFF & 2 & 0 & 0 & 3 & 10.00 \\
\hline $89 \mathrm{~N}$ & Malenchus andrassyi Merny, 1971 & RFF & 2 & 0 & 0 & 1 & 3.33 \\
\hline 90 & Malenchus bryophilus (Steiner, 1914) & RFF & 2 & 1 & 0 & 0 & 3.33 \\
\hline $91 \mathrm{~N}$ & Malenchus neosulcus Geraert et Raski, 1986 & RFF & 2 & 4 & 2 & 1 & 23.33 \\
\hline $92 \mathrm{~N}$ & Cephalenchus hexalineatus (Geraert, 1962) & RFF & 2 & 1 & 0 & 7 & 26.67 \\
\hline $93 \mathrm{~N}$ & Cephalenchus leptus Siddiqi, 1963 & RFF & 2 & 0 & 0 & 2 & 6.67 \\
\hline 94 & Lelenchus leptosoma (de Man, 1880) & RFF & 2 & 0 & 0 & 2 & 6.67 \\
\hline $95 \mathrm{~N}$ & Ditylenchus acutus (Khan, 1965) ${ }^{7)}$ & $\mathrm{F}$ & 2 & 0 & 0 & 1 & 3.33 \\
\hline 96 & Ditylenchus elegans Zell, 1988 & $\mathrm{~F}$ & 2 & 0 & 0 & 1 & 3.33 \\
\hline $97 \mathrm{~N}$ & Ditylenchus equalis Heyns, 1964 & $\mathrm{~F}$ & 2 & 1 & 0 & 0 & 3.33 \\
\hline $98 \mathrm{~N}$ & Ditylenchus filenchulus Brzeski, 1991 & $\mathrm{~F}$ & 2 & 1 & 0 & 1 & 6.67 \\
\hline $99 \mathrm{~N}$ & Ditylenchus longimatricalis (Kazachenko, 1975) & $\mathrm{F}$ & 2 & 0 & 0 & 2 & 6.67 \\
\hline $100 \mathrm{~N}$ & Ditylenchus lutonenensis (Siddiqi, 1980) ${ }^{7}$ & $\mathrm{~F}$ & 2 & 9 & 4 & 4 & 56.67 \\
\hline $1 \mathrm{~N}$ & Ditylenchus $t$ & $\mathrm{~F}$ & 2 & 0 & 0 & 1 & 3.33 \\
\hline 102 & Ditylenchus s & $\mathrm{F}$ & 2 & 1 & 0 & 0 & 3.33 \\
\hline 103 & Ditylenchus sp. 2 & $\mathrm{~F}$ & 2 & 1 & 0 & 4 & 16.67 \\
\hline $104 \mathrm{~N}$ & Bitylenchus bryobius (Sturhan, 1966) Jairajpuri, $1982^{8)}$ & PP & 3 & 0 & 0 & 1 & 3.33 \\
\hline 105 & Bitylenchus dubius (Bütschli, 1873) Filipjev, 1934 ${ }^{8)}$ & PP & 3 & 4 & 4 & 6 & 46.67 \\
\hline 106 & Nagelus sp. juv. & $\mathrm{PP}$ & 3 & 0 & 1 & 0 & 3.33 \\
\hline 107 & Pratylenchus penetrans (Cobb, 1917) & PP & 3 & 1 & 0 & 1 & 6.67 \\
\hline 108 & Pratylenchus pratensis (de Man, 1880) & PP & 3 & 1 & 3 & 0 & 13.33 \\
\hline 109 & Pratylenchus thornei Sher et Allen, 1953 & PP & 3 & 0 & 1 & 1 & 6.67 \\
\hline 110 & Hoplotylus femina s'Jacob, 1959 & $\mathrm{PP}$ & 3 & 0 & 0 & 1 & 3.33 \\
\hline 111 & Helicotylenchus canadensis Waseem, 1961 & PP & 3 & 0 & 2 & 0 & 6.67 \\
\hline 112 & $\begin{array}{l}\text { Helicotylenchus digonicus Perry in Perry, Darling et } \\
\text { Thorne, } 1959\end{array}$ & $\mathrm{PP}$ & 3 & 1 & 2 & 4 & 23.33 \\
\hline 113 & Helicotylenchus exallus Sher, 1966 & PP & 3 & 0 & 2 & 0 & 6.67 \\
\hline 114 & Helicotylenchus pseudorobustus (Steiner, 1914) & PP & 3 & 0 & 1 & 3 & 13.33 \\
\hline 115 & Helicotylenchus varicaudatus Yuen, 1964 & PP & 3 & 0 & 1 & 1 & 6.67 \\
\hline 116 & Helicotylenchus vulgaris Yuen, 1964 & $\mathrm{PP}$ & 3 & 0 & 0 & 1 & 3.33 \\
\hline 117 & Rotylenchus robustus (de Man, 1876) acc. Brzeski (1998) & PP & 3 & 0 & 2 & 2 & 13.33 \\
\hline 118 & Heterodera juv. & PP & 3 & 0 & 0 & 1 & 3.33 \\
\hline 119 & Paratylenchus nanus Cobb, 1923 group ${ }^{9)}$ & PP & 2 & 2 & 0 & 2 & 13.33 \\
\hline 120 & Paratylenchus projectus Jenkins, 1956 & PP & 2 & 0 & 1 & 0 & 3.33 \\
\hline $121 \mathrm{~N}$ & Paratylenchus similis Khan, Prasad et Mathur, 1967 & PP & 2 & 0 & 2 & 0 & 6.67 \\
\hline 122 & Paratylenchus straeleni (de Coninck, 1931) & PP & 2 & 7 & 9 & 8 & 80.00 \\
\hline 123 & Paratylenchus sp. & $\mathrm{PP}$ & 2 & 0 & 1 & 0 & 3.33 \\
\hline 124 & Xenocriconemella macrodora (Taylor, 1936) & PP & 3 & 5 & 3 & 3 & 36.67 \\
\hline
\end{tabular}


Criconema annuliferum (de Man, 1921)

Deladenus aridus Andrássy, 1957

tylenchid invasive juvs. sp. 1

tylenchid invasive juvs. sp. 2

Enoplida Filipjev, 1929

Prismatolaimus dolichurus de Man, 1880

Prismatolaimus matoni Mulk et Coomans, 1979

Prismatolaimus sp. 1 (cf. primitivus Loof, 1971) ${ }^{10)}$

Prismatolaimus sp. 2 (cf. stenolaimoides Loof, 1971) ${ }^{10)}$

Stenonchulus troglodytes W. Schneider, 1940

Tripyla affinis de Man, 1880

Tripyla filicaudata de Man, 1880

Tripyla setifera Bütschli, 1873

Trischistoma gracile Andrássy, 1985

Tobrilia sp. (cf. longicaudata Andrássy, 1968) ${ }^{10)}$

Alaimida Siddiqi, 1983

Alaimus meyli Andrássy, 1961

Alaimus parvus Thorne, 1939]

Alaimus primitivus de Man, 1880 / jaulasali Siddiqi et Husain, $1967^{11)}$

Alaimus sp.

Paramphidelus dolichurus (de Man, 1876)

Paramphidelus pseudobulbosus (Altherr, 1936) juv.

Paramphidelus pusillus (Thorne, 1936)

Diphtherophorida Loof, 1991

Diphtherophora communis de Man, 1880

Diphtherophora sp.

Tylolaimophorus minor (Thorne, 1939)

Tylolaimophorus typicus de Man, 1880

Tylolaimophorus sp.

Trichodorus sparsus Szczygiel, 1968

Mononchida Jairajpuri, 1969

Clarkus papillatus (Bastian, 1965)

Coomansus parvus (de Man, 1880)

Coomansus zschokkei (Menzel, 1913)

Prionchulus muscorum (Dujardin, 1845) s.1. ${ }^{12)}$

Prionchulus punctatus Cobb, 1917

Mylonchulus brachyuris (Bütschli, 1873)

Miconchus hopperi Mulvey, 1962

Anatonchus tridentatus (de Man, 1876)

Dorylaimida Pearse, 1942

Nygolaimus sp. juv.

Prodorylaimus sp. juv.

Mesodorylaimus bastiani (Bütschli, 1873)

Crassolabium circuliferum (Loof, 1961)

Crassolabium ettersbergense (de Man, 1885)

Crasolabium medianum (Eroshenko, 1976)

Crasolabium sp. juv.

Epidorylaimus lugdunensis (de Man, 1880)

Epidorylaimus cf. humilior (Andrássy, 1959) ${ }^{10)}$

Eudorylaimus bureshi (Andrássy, 1958)

$\begin{array}{cccccc}\mathrm{PP} & 3 & 0 & 0 & 3 & 10.00 \\ \mathrm{~F} & 2 & 2 & 0 & 3 & 16.67 \\ \mathrm{~F} & 2 & 0 & 4 & 3 & 23.33 \\ \mathrm{PP} & 3 & 0 & 2 & 5 & 23.33 \\ & & & & & \\ \mathrm{~B} & 3 & 0 & 1 & 0 & 3.33 \\ \mathrm{~B} & 3 & 2 & 6 & 7 & 50.00 \\ \mathrm{~B} & 3 & 0 & 0 & 1 & 3.33 \\ \mathrm{~B} & 3 & 1 & 1 & 3 & 16.67 \\ \mathrm{P} & 3 & 0 & 0 & 3 & 10.00 \\ \mathrm{P} & 3 & 1 & 0 & 1 & 6.67 \\ \mathrm{P} & 3 & 1 & 0 & 4 & 16.67 \\ \mathrm{P} & 3 & 0 & 3 & 3 & 20.00 \\ \mathrm{P} & 3 & 0 & 0 & 2 & 6.67 \\ \mathrm{P} & 3 & 0 & 0 & 1 & 3.33\end{array}$

$\begin{array}{llllll}\text { B } & 4 & 0 & 2 & 4 & 20.00\end{array}$

$\begin{array}{llllll}\text { B } & 4 & 1 & 1 & 4 & 20.00\end{array}$

$\begin{array}{llllll}\text { B } & 4 & 4 & 4 & 6 & 46.67\end{array}$

$\begin{array}{llllll}\text { B } & 4 & 0 & 0 & 1 & 3.33\end{array}$

$\begin{array}{llllll}\text { B } & 4 & 0 & 0 & 4 & 13.33\end{array}$

$\begin{array}{llllll}\mathrm{B} & 4 & 0 & 0 & 2 & 6.67\end{array}$

$\begin{array}{llllll}\mathrm{B} & 4 & 0 & 0 & 1 & 3.33\end{array}$

$\begin{array}{llllll}\mathrm{F} & 3 & 0 & 0 & 3 & 10.00\end{array}$

$\begin{array}{llllll}\mathrm{F} & 3 & 1 & 3 & 7 & 36.67\end{array}$

$\begin{array}{llllll}\mathrm{F} & 3 & 4 & 3 & 0 & 23.33\end{array}$

$\begin{array}{llllll}\mathrm{F} & 3 & 0 & 0 & 3 & 10.00\end{array}$

$\begin{array}{llllll}\mathrm{F} & 3 & 0 & 0 & 1 & 3.33\end{array}$

$\begin{array}{llllll}\mathrm{PP} & 4 & 4 & 2 & 2 & 26.67\end{array}$

$\begin{array}{llllll}\mathrm{P} & 4 & 1 & 9 & 10 & 66.67\end{array}$

$\begin{array}{llllll}\mathrm{P} & 4 & 0 & 0 & 1 & 3.33\end{array}$

$\begin{array}{llllll}\mathrm{P} & 4 & 0 & 6 & 3 & 30.00\end{array}$

$\begin{array}{llllll}\mathrm{P} & 4 & 3 & 0 & 2 & 16.67\end{array}$

$\begin{array}{llllll}\mathrm{P} & 4 & 3 & 3 & 4 & 33.33\end{array}$

$\begin{array}{llllll}\mathrm{P} & 4 & 1 & 3 & 6 & 33.33\end{array}$

$\begin{array}{llllll}\mathrm{P} & 4 & 0 & 0 & 1 & 3.33\end{array}$

$\begin{array}{llllll}\mathrm{P} & 4 & 0 & 3 & 0 & 10.00\end{array}$

$\begin{array}{llllll}\mathrm{P} & 5 & 0 & 1 & 1 & 6.67\end{array}$

$\begin{array}{llllll}\mathrm{O} & 5 & 0 & 4 & 3 & 23.33\end{array}$

$\begin{array}{llllll}\mathrm{O} & 5 & 5 & 6 & 9 & 66.67\end{array}$

$\begin{array}{llllll}\mathrm{O} & 4 & 1 & 1 & 1 & 10.00\end{array}$

$\begin{array}{llllll}\mathrm{O} & 4 & 0 & 0 & 1 & 3.33\end{array}$

$\begin{array}{llllll}\mathrm{O} & 4 & 0 & 5 & 1 & 20.00\end{array}$

$\begin{array}{llllll}\mathrm{O} & 4 & 0 & 0 & 1 & 3.33\end{array}$

$\begin{array}{llllll}\mathrm{O} & 4 & 0 & 1 & 1 & 6.67\end{array}$

$\begin{array}{llllll}\mathrm{O} & 4 & 0 & 1 & 1 & 6.67\end{array}$

$\begin{array}{llllll}\mathrm{O} & 4 & 3 & 1 & 4 & 26.67\end{array}$ 


\begin{tabular}{|c|c|c|c|c|c|c|c|}
\hline 170 & Eudorylaimus carteri (Bastian, 1865) & $\mathrm{O}$ & 4 & 1 & 1 & 0 & 6.67 \\
\hline $171 \mathrm{~N}$ & Eudorylaimus discolaimiodeus (Andrássy, 1958) & $\mathrm{O}$ & 4 & 4 & 3 & 6 & 43.33 \\
\hline $172 \mathrm{~N}$ & Eudorylaimus familiaris Winiszewska-Slipinska, 1987 & $\mathrm{O}$ & 4 & 1 & 0 & 0 & 3.33 \\
\hline 173 & Eudorylaimus silvaticus Brzeski, 1960 & $\mathrm{O}$ & 4 & 8 & 4 & 5 & 56.67 \\
\hline 174 & Eudorylaimus similis (de Man, 1876) s.l. ${ }^{13)}$ & $\mathrm{O}$ & 4 & 9 & 8 & 7 & 80.00 \\
\hline 175 & Eudorylaimus sp. 1 & $\mathrm{O}$ & 4 & 0 & 0 & 1 & 3.33 \\
\hline 176 & Eudorylaimus sp. 2 & $\mathrm{O}$ & 4 & 0 & 0 & 1 & 3.33 \\
\hline 177 & Eudorylaimus sp. 3 & $\mathrm{O}$ & 4 & 0 & 1 & 0 & 3.33 \\
\hline $178 \mathrm{~N}$ & Microdorylaimus longicollis (Brzeski, 1964) & $\mathrm{O}$ & 4 & 0 & 0 & 1 & 3.33 \\
\hline 179 & Microdorylaimus parvus (de Man, 1880) & $\mathrm{O}$ & 4 & 0 & 1 & 1 & 6.67 \\
\hline 180 & Ecumenicus monohystera (de Man, 1880) & $\mathrm{O}$ & 5 & 1 & 2 & 2 & 16.67 \\
\hline 181 & Aporcelaimellus obtusicaudatus (Bastian, 1865) s.1. ${ }^{12)}$ & $\mathrm{O}$ & 5 & 4 & 10 & 9 & 76.67 \\
\hline 182 & Aporcelaimus sp. juv. & $\mathrm{O}$ & 5 & 0 & 1 & 0 & 3.33 \\
\hline 183 & Metaporcelaimus labiatus (de Man, 1880) & $\mathrm{O}$ & 5 & 2 & 6 & 2 & 33.33 \\
\hline 184 & Sectonema sp. juv. & $\mathrm{P}$ & 5 & 0 & 1 & 1 & 6.67 \\
\hline 185 & Nordiidae sp. (one female) & PP & 4 & 0 & 0 & 2 & 6.67 \\
\hline $186 \mathrm{~N}$ & Longidorella cf. murithi Altherr, $1950^{14)}$ & PP & 4 & 0 & 2 & 5 & 23.33 \\
\hline 187 & Pungentus engadinensis (Altherr, 1950) & PP & 4 & 0 & 1 & 1 & 6.67 \\
\hline 188 & Pungentus silvestris (de Man, 1912) & PP & 4 & 1 & 4 & 6 & 36.67 \\
\hline 189 & Longidorus sp. juv. & PP & 5 & 1 & 0 & 0 & 3.33 \\
\hline 190 & Xiphinema sp. juv. & PP & 5 & 0 & 1 & 0 & 3.33 \\
\hline 191 & Oxydirus oxycephalus (de Man, 1885) & $\mathrm{O}$ & 5 & 0 & 3 & 0 & 10.00 \\
\hline 192 & Dorylaimellus sp. & $\mathrm{O}$ & 5 & 0 & 0 & 5 & 16.67 \\
\hline $193 \mathrm{~N}$ & Tylencholaimus constrictus Vinciguerra, 1986 & $\mathrm{~F}$ & 4 & 0 & 0 & 6 & 20.00 \\
\hline 194 & Tylencholaimus minimus de Man, 1876 & $\mathrm{~F}$ & 4 & 0 & 2 & 0 & 6.67 \\
\hline 195 & Tylencholaimus mirabilis (Bütschli, 1873) & $\mathrm{F}$ & 4 & 8 & 10 & 8 & 86.67 \\
\hline $196 \mathrm{~N}$ & Tylencholaimus minutus Vinciguerra, 1986 & $\mathrm{~F}$ & 4 & 0 & 1 & 1 & 6.67 \\
\hline $197 \mathrm{~N}$ & $\begin{array}{l}\text { Tylencholaimus sp. (cf. paradoxus Loof et Jairajpuri, 1968) } \\
\text { 10) }\end{array}$ & $\mathrm{F}$ & 4 & 0 & 3 & 1 & 13.33 \\
\hline \multirow[t]{3}{*}{198} & Tylencholaimus stecki Steiner, 1914 & $\mathrm{~F}$ & 4 & 0 & 5 & 3 & 26.67 \\
\hline & Total number of species & & & 87 & 115 & 167 & 198 \\
\hline & Total number of genera & & & 51 & 68 & 86 & 98 \\
\hline
\end{tabular}

Key: ${ }^{1)}$ Zell (1990) synonymized $A$. eradicitus with A. lagenoferrus when gave redescription of the latter. ${ }^{2)}$ Andrássy (2007), p. 34, synonymized $A$. lagenoferrus with A. sacchari Hooper, 1958 but gave no details. The genus Aphelenchoides needs thorough revision. ${ }^{3)}$ Specimens in poor condition so the number of longitudinal cuticle incisures is uncertain. ${ }^{4)}$ Brzeski (1997) synonymized $F$. aquilonius with $F$. orbus Andrássy, 1954, specimens from Vihorlat are closer to the original description of the former than to the latter. ${ }^{5)}$ Brzeski (1997) synonymized 11 Filenchus species with $F$. misellus. It is hard to say whether morphological variability in those small Filenchus is intra-specific character or whether reflects a group of close related species (Háněl, 2000). ${ }^{6}$ Brzeski (1998) synonymized $F$. spicatus with $F$. acris (Brzeski, 1986), specimens from Vihorlat are closer to the original description of the former than to the latter. ${ }^{7}$ Andrássy (2007) accepts Nothotylenchus acutus Khan, 1965 and Safianema lutonense Siddiqi, 1980 whereas Brzeski (1998) places those species into the genus Ditylenchus. For the practical reasons of quantitative evaluation of the material the

two species are in kept in the genus Ditylenchus because of variation in pharynx morphology in juvenile stages. ${ }^{8)}$ Brzeski (1998) places those species in the genus Tylenchorhynchus. ${ }^{91}$ Resting juvenile stages were not found so species couldn't be determined with certainty. ${ }^{10)}$ Insufficient material for precise determination. ${ }^{11)}$ Material is partly damaged and may include both species. ${ }^{12)}$ There may be a group of very similar and hardly distinguishable species. ${ }^{13)}$ According to Loof (1999) E. similis and E. schraederi Altherr, 1974 are the same species. ${ }^{14)}$ Key according to Andrássy (2009) leads to L. murithi but there are some differences from the description. 


\section{References}

ALPHEI, J. (1998): Differences in soil nematode community structure of beech forests: Comparison between a mull and a moder soil. Appl. Soil Ecol., 9: 9 - 15. DOI: 10.10 16/S0929-1393(98)00047-X

ANDRÁSSY, I. (1996): Free-living nematodes in the Bükk Mountains, Hungary. In: MAHUNKA, S. (Eds) The fauna of the Bükk National Park. Volume II. Budapest, Hungarian Natural History Museum, pp. $33-63$

ANDRÁSSY, I. (2005): Free-living nematodes of Hungary (Nematoda errantia), Volume I. Budapest, Hungarian Natural History Museum and Systematic Zoology Research Group of the Hungarian Academy of Sciences, 655 pp.

ANDRÁSSY, I. (2007): Free-living nematodes of Hungary (Nematoda errantia), Volume II. Budapest, Hungarian Natural History Museum and Systematic Zoology Research Group of the Hungarian Academy of Sciences, 496 pp.

ANDRÁSSY, I. (2009): Free-living nematodes of Hungary (Nematoda errantia), Volume III. Budapest, Hungarian Natural History Museum and Systematic Zoology Research Group of the Hungarian Academy of Sciences, 608 pp.

Bongers, T. (1988): De nematoden van Nederland. Utrecht, Koninklijke Nederlandse Natuurhistorische Vereniging, $408 \mathrm{pp}$.

Bongers, T., Bongers, M. (1998): Functional diversity of nematodes. Appl. Soil Ecol., 10: 239 - 251. DOI: 10.1016/ S0929-1393(98)00123-1

Bongers, T., Ferris, H. (1999): Nematode community structure as a bioindicator in environmental monitoring. Trends Ecol. Evolut., 14: 224 - 228. DOI: 10.1016/S01695347(98)01583-3

BRZESKI, M. W. (1997): Redescription of some species of the genus Filenchus Andrássy, 1954 (Nematoda, Tylenchidae). Misc. Zool., 20: $45-64$

BRZESKI, M. W. (1998): Nematodes of Tylenchina in Poland and temperate Europe. Warszawa, Muzeum i Instytut Zoologii Polska Akademia Nauk, 397 pp.

BÜTTNER, V. (1989): Untersuchungen zur Ökologie der Nematoden eines Kalkbuchenwaldes. Nematologica, 35: 234 - 247. DOI: 10.1163/002825989X00377

ČEREVKOVÁ, A., RENČO, M. (2009): Soil nematode community changes associated with windfall and wildfire in forest soil at the High Tatras National Park, Slovak Republic. Helminthologia, 46: 123 - 130. DOI: 10.2478/ s11687-009-0024-9

Ekschmitt, K., BAKOnYi, G., Bongers, M., Bongers, T., Boström, S., Dogan, H., Harrison, A., NAgY, P., O'Donnell, A. G., Papatheodorou, E. M., Sohlenius, B., Stamou, G. P., Wolters, V. (2001): Nematode community structure as indicator of soil functioning in European grassland soils. Eur. J. Soil Biol., 37: 263 - 268. DOI: 10.1016/S1164-5563(01)01095-0

ETTEMA, C. H. (1998): Soil nematode diversity: species coexistence and ecosystem function. J. Nematol., 30: $159-$ 169

FISCUS, D. A., NeHER, D. A. (2002): Distinguishing sensitivity of free-living soil nematode genera to physical and chemical disturbances. Ecol. Appl., 12: 565 - 575. DOI: 10.1890/1051-0761(2002)012[0565:DSOFLS]2.0.CO;2

FreckMAN, D. W., ETtemA, C. H. (1993): Assessing nematode communities in agroecosystems of varying human intervention. Agric. Ecosyst. Environ., 45: $239-$ 261. DOI: 10.1016/0167-8809(93)90074-Y

HÁNĚL, L., (1992): Soil nematodes in a meadow-spruce forest ecotone. Acta Soc. Zool. Bohemoslov., 56: 265 - 278 (published in 1993)

HÁNĚL, L. (1996a): Soil nematodes (Nematoda) in forest ecosystems of the Křivoklátsko Biosphere Reserve, Czech Republic. Čas. Nár. Muz. ̌̌. Př́rodověd., 165: 91 - 102

HÁNĚL, L. (1996b): Soil nematodes in five spruce forests of the Beskydy mountains, Czech Republic. Fundam. Appl. Nematol., 19: $15-24$

HÁNĚL, L. (2000): Morphological variability in single female progenies of Cephalenchus hexalineatus (Geraert, 1962) and Filenchus misellus (Andrássy, 1958) (Nematoda: Tylenchida). Ann. Zool., 50: 225 - 231

HÁNĚL, L. (2004): Response of soil nematodes inhabiting spruce forests in the Šumava Mountains to disturbance by bark beetles and clear-cutting. Forest Ecol. Manag., 202: 209-225. DOI: 10.1016/j.foreco.2004.07.027

HÁNĚL, L. (2009): Species and genera of soil nematodes inhabiting tree plantations on colliery spoils near Sokolov. In: TAjovský, K., SchlaghamerskÝ, J., PIŽL V. (Eds) Contributions to soil zoology in Central Europe III. České Budějovice, ISB BC AS CR, v.v.i., pp. 53 - 58

HÁNĚL, L., ČEREVKOVÁ, A. (2006): Diversity of soil nematodes in meadows of the White Carpathians. Helminthologia , 43: 109 - 116. DOI: 10.2478/s11687-0060021-1

Hugot, J.-P., BAujard, P., Morand, S. (2001): Biodiversity in helminths and nematodes as a field of study: an overview. Nematology, 3: 199 - 208. DOI: 10.1163/15685 4101750413270

LiŠKovÁ, M., ČERevkovÁ, A., HÁNĚL, L. (2008): Nematode communities of forest ecosystems in association with various soil orders. Russ. J. Nematol., 16: $129-142$. Loof, P. A. A. (1999): Nematoda: Adenophorea (Dorylaimida). Heidelberg, Berlin, Spektrum Akademischer Verlag, 264 pp.

OKADA, H., KADOTA, I. (2003): Host status of 10 fungal isolates for two nematode species, Filenchus misellus and Aphelenchus avenae. Soil Biol. Biochem., 35: 1601 - 1607. DOI: 10.1016/j.soilbio.2003.08.004

PopOVICI, I. (1989): Soil nematode communities in the Carpathian beech forests of Romania. Studia Univ. BabeşBolyai, Biologia, 34: 38 - 44

PopovicI, I., CiOBANU, M. (2000): Diversity and distribution of nematode communities in grasslands from Romania in relation to vegetation and soil characteristics. Appl. Soil Ecol., 14: 27 - 36. DOI: 10.1016/S09291393(99)00048-7

Postma-Blaauw, M. B., DE Vries, F. T., DE Goede, R. G. M., Bloem, J., Faber, J. H., BrussaArd, L. (2005): Within-trophic group interactions of bacterivorous nematode species and their effects on the bacterial 
community and nitrogen mineralization. Oecologia, 142: 428 - 439. DOI: 10.1007/s00442-004-1741-x

Ruess, L., SChMidt, I. K., Michelsen, A., Jonasson, S. (2001): Manipulations of a microbial based soil food web at two arctic sites - evidence of species redundancy among the nematode fauna? Appl. Soil Ecol., 17: 19 - 30. DOI: 10.1016/S0929-1393(00)00131-1

ŠÁLY, A. (1983): Free-living nematodes in the Slovak Socialist Republic. Bratislava, Publishing House Veda, 160 pp. (in Slovak)

ŠÁLY, A. (1985): Production of free living nematodes in the Protected landscape area of the Slovak Paradise. Ekológia (ČSSR), 4: 185 - 209

STATSOFT INC., 2001. STATISTICA CZ (Softwarový systém na analýzu dat) verze 6 [(Software system for data analysis) Release 6. (in Czech and English)

VinCIGUERRA, M. T. (1979): Role of nematodes in the biological processes in the soil. Boll. Zool., 46: $363-374$. DOI: $10.1080 / 11250007909440312$
WASILEWSKA, L. (1979): The structure and function of soil nematode communities in natural ecosystems and agrocenoses. Pol. ecol. Stud., 5: 97 - 145

YEATES, G. W. (1994): Modification and qualification of the nematode maturity index. Pedobiologia, 38: 97 - 101

YEATES, G. W. (2003): Nematodes as soil indicators: functional and biodiversity aspects. Biol. Fertil. Soils, 37: 199 - 210. DOI: 10.1007/s00374-003-0586-5

YeATES, G. W. (2007): Abundance, diversity, and resilience of nematode assemblages in forest soils. Can. J. For. Res., 37: 216 - 225. DOI: 10.1139/X06-172

Yeates, G. W., Bongers, T., DE Goede, R. G. M., FreCKMAN, D. W., GERGIEVA, S. S. (1993): Feeding habits in nematode families and genera: an outline for soil ecologists. J. Nematol., 25: $315-331$

ZELL, H. (1990): Nematoden eines Buchenwaldbodens. 12. Die Aphelenchen (Nematoda, Aphelenchida). Carolinea, 48: $121-130$ 